\title{
FUELLING THE ECONOMY: A CRITICAL REVIEW OF LIPUID FUELS REGULATION IN SOUTH AFRICA
}

\author{
Pamela Mondliwa \\ Centre for Competition, Regulation and \\ Economic Development \\ pamelam@uj.ac.za
}

Received: June 2014

\author{
Simon Roberts* \\ Centre for Competition, Regulation and \\ Economic Development \\ sroberts@uj.ac.za
}

Accepted: September 2014

\begin{abstract}
This article reviews the regulation of liquid fuels in South Africa over the past decade. We first briefly assess the regulatory regime and how the regulatory functions have been carried out. We then consider the influence of security of supply concerns on regulation and highlight that it has favoured local refining interests rather simply ensuring supply to local fuel customers. The record of price regulation at different levels from refinery to retail is assessed, revealing the margins which had been allowed through the way in which the import parity price calculation had been done, which set prices that were higher than actual import prices would have been. The article further highlights how regulation has failed to take into account the special position of Sasol, notwithstanding the recommendations of the Windfall Tax Task Team and the reasons why the recommendations were not adopted by National Treasury based on expectations of investment. The case of natural gas provides a contrast, being subject to a recent regulatory framework, and we consider whether learnings from regulation in other parts of the value chain have been used in setting out new regulations.
\end{abstract}

Keywords

Regulation, market power, fuel, natural gas

\#Ms Pamela Mondliwa is a researcher at the Centre for Competition, Regulation and Economic Development, South Africa.

*Prof Simon Roberts is the Director of the Centre for Competition, Regulation and Economic Development, University of Johannesburg, South Africa. 


\section{INTRODUCTION}

Economic regulation has three main rationales. First, where there is entrenched market power most obviously where there are natural monopolies - economic regulation may be adopted to constrain the exercise of this power. Second, regulation of access may be used to place requirements on participants through licensing. Third, regulation may be used to ensure socioeconomic objectives such as universal service are met.

In South Africa, as in other countries, regulation is in the main about regulating the 'natural monopoly' parts of the economy that were state-owned and have been privatised. In some cases, the functions of economic regulation are undertaken by government departments. The regulatory mandate and functions over the South African fuel industry largely lie with the Department of Energy, while regulation of piped gas and of petroleum pipelines is the mandate of the National Energy Regulator of South Africa, Nersa. In the case of liquid fuel, the industry is subject to scale economies, and there has been substantial state support and prior ownership of the largest producer, Sasol. These factors need to be considered alongside the pipeline network, owned by the transport utility, Transnet.

The role of economic regulation can be understood in terms of prices and access (Viscusi et al., 2000). Prices are controlled or capped because otherwise they would be set at monopoly levels. $\varepsilon$ conomic regulation can also require access to be provided to essential facilities or inputs which cannot easily be replicated and are controlled by the incumbent. This is, however, a relatively narrow and static delineation of the scope of regulation, as it is focused on existing infrastructure and static considerations of efficiency. The case for economic regulation is also premised on the existence of significant market failure resulting from economies of scale and scope in production, from information imperfections in market transactions, from the existence of incomplete markets and externalities and from resulting income and wealth distribution effects (Jalilian et al., 2006). This implies that economic regulation is much more challenging in an industrialising economy where major investments are required yet institutional capacity is relatively weak. Influencing the structure of incentives, including prices, is also a critical part of industrial policy to alter the development path (see, for example, Amsden, 2003) and regulation is part of these choices.

Throughout its history the liquid fuels industry in South Africa has been granted a special status justified either through the nature of the retail petrol industry or through its strategic status post World War II. The special status led to the exemption from competition law, a range of formal and informal institutions of cooperation between industry participants and with government, and regulation to keep the status quo. The history of regulation in the refining and marketing of petrochemical products entrenched a long-standing culture of coordinated behaviour between oil companies. As a consequence the heavily supported liquid fuels value chain has been plagued by a series of anti-competitive conduct not only in the liquid fuel markets but in related product markets (Das Nair et al., 2012).

In an effort to ensure security of supply under apartheid the government of the day initially allowed the refining industry to regulate the market and control price and entry and exit. Even when the regulatory role was institutionalised it was designed to incentivise the oil companies to continue to produce in South Africa and to ensure the success of the synthetic fuel industry. Consequently, fuel regulation has generally been in favour of the industry players (Rustomjee et al., 2007). 
This article reviews the regulation of liquid fuels in South Africa over the past decade at two levels. We first briefly describe the regulatory regime and how the regulatory functions have been carried out. Section 2 considers the question of security of supply and regulation, including the impact on investment and supply decisions at the level of refining, and the impact on linkages between fuel refining and chemicals production. Section 3 examines the role of regulation in terms of constraining the exertion of market power. Section 4 assesses the regulation of gas prices in light of what can be learned from the review of regulation of liquid fuels. Section 5 concludes.

\subsection{Overview of liquid fuel regulation}

Any assessment of the regulation system must be cognisant of what the regulation is aiming to achieve. According to the DoE, the objectives of fuel industry regulation are to: ensure internationally competitive pricing of petroleum products that will enable investment into the sector and attract new entrants, develop, maintain and implement the basic fuel pricing system, a Regulatory Accounting System and fixed retail margin for illuminating paraffin (DOE, 2012). This is in line with the objectives of the Petroleum Products Act of 1977 as amended in 2003 and 2005:

- promoting an efficient manufacturing, wholesaling and retailing petroleum industry;

- facilitating an environment conducive to efficient and commercially justifiable investment;

- creating employment opportunities and developing small business in the petroleum sector;

- ensuring the countrywide availability of petroleum products at competitive prices; and

- promoting access to affordable petroleum products by low-income consumers for household use.

The Dor regulates the fuel industry by controlling prices and access to the market. The DoE further controls the importation and exportation of crude oil, petroleum products and blending components, together with ITAC. Participation in the industry is controlled through the licensing of all activities in the industry, including wholesale, retail, operation of pipelines and storage facilities. Petroleum products' specifications and standards are also set by the Dor.

Liquid fuels prices are regulated at various levels, although not all prices are regulated and some are maximum prices. The Dor sets the licensing requirements and regulations pertaining to: the importation and exportation of crude oil, petroleum products and blending components; operation of storage facilities and loading facilities, including approval of tariff structures; manufacturing of petroleum products; wholesale of fuels, including the maximum price of diesel and illuminating paraffin; retailing of fuels, including the pump price of petrol by grade and location and the maximum price for LPG and illuminating paraffin; recovery of transport costs; retail and wholesale margins; and petroleum products specifications and standards. The petroleum pipelines tariffs are controlled by the National Energy Regulator of South Africa (Nersa) and the fuel levy is determined by National Treasury.

The structure of petrol price has remained essentially the same since the 1950 s consisting of:

- the basic fuel price (BFP) (cost of importing fuel), transport component (cost of transporting fuel to a specific location in $S A$ ); 
- tax component (various government levies); a wholesale margin (MPAR) - oil company margin;

- a retail margin - dealer margin and other components that have varied over time.

The biggest component of the petrol pump price is the basic fuel price (BFP) (TABLE l).

TABLE 1: Petrol Pump Price components

\begin{tabular}{lcc}
\hline & Component & Contribution \\
& $(c / I)$ & $\%$ \\
\hline BFP & 753.55 & $58.1 \%$ \\
Government duties and levies & 312.65 & $24.1 \%$ \\
Zone differential & 28.90 & $2.2 \%$ \\
Industry margin & 31.00 & $2.4 \%$ \\
Service differential & 28.80 & $2.2 \%$ \\
\hline Dealer margin & 139.10 & $10.7 \%$ \\
Incremental inland transport recovery levy & 3.00 & $0.2 \%$ \\
\hline
\end{tabular}

Source: SAPIA 2013 Annual Report

Prior to the development of the indigenous refining industry, regulation of the retail fuel sector was carried out by the industry, which controlled the price as well as entry into the market. The state took over the price-setting process for petrol sales as well as retail and wholesale margins in 1946. Between 1946 and 1970 the state began to develop the indigenous fuel industry, regulated refinery gate, wholesale and retail prices and restricted imports (Price Control Act 1960) (Marquard, 2006). The development of the synthetic fuel industry in the 1950s and the beginning of the oil embargo in 1970 required modifications to regulation systems to accommodate the state's oil security strategy (Petroleum Act 1977).

In 1954 government secured the conclusion of agreements known as the Sasol Supply Agreements or the Main Supply Agreement (MSA) between Sasol and the other oil companies. These agreements effectively constituted a government-brokered and -sanctioned form of private regulation, obliging the oil companies to service their marketing requirements in the inland region by purchasing all of Sasol's production volumes pro-rata to their market shares (Competition Commission, 2012).

The price of these volumes was based on the 'in-bond landed cost' ('IBLC'), calculated on the basis of an import parity price for fuel products, that is, a price in line with the notional costs of importing fuel. The essence of the MSA was that the oil companies would purchase Sasol's production of petroleum products up to certain maximum volumes from defined sources of supply, and Sasol would not market petroleum products save for certain exceptions. The petroleum industry was also exempted from the competition law between 1988 and 2001.

There have been a number of reviews of liquid fuels regulation, including the Windfall Tax Task Team (Rustomjee et al., 2007), Moerane Inquiry (2005), and Liquid Fuels Industry Task Team (1994). Although these reviews have had different focuses, one can observe common threads 
regarding their analysis of liquid fuels regulation in South Africa. The reviews have advocated for re-regulation of the fuel industry, noting that it often advantaged the industry insiders or oil majors.

\section{SECURITY OF SUPPLY AND REGULATORY CHALLENGES}

Liquid fuel has been viewed as a strategic necessity in South Africa given its importance to the economy. However, while obviously a critical product for economic activity it is also readily transported internationally. Under apartheid there was a rationale for increasing local production to guard against the possible effect of sanctions; however, if the feedstock (crude oil) is still imported then it does not reduce dependence on international sources. There is only a foreign exchange effect, as imports of crude oil are cheaper than those of refined product.

It is thus important to ask what security of supply means now, and how it relates to investment and increased participation.

Security of supply can be understood in non-economic terms and as an objective of energy policy. However, it can also be understood in terms of the difference between the private returns (that is, the returns to the individual producer) and the wider effect on the economy from a supply disruption. The producer simply loses sales, while the knock-on effect which is external to the producer is much greater because of the indispensable nature of fuel to much economic activity.

The difference between the private and social return implies that the private agent will underinvest. This is the case whether we are considering production capacity or storage and distribution capabilities. Why would a private agent invest in capacity that is unused $95 \%$ of the time, even though the wider economic cost of not having the capacity $5 \%$ of the time is huge?

It bears emphasising that this is not about refining capacity but about adequate sourcing of refined product and its distribution. Even if the country is self-sufficient in the capacity to make refined products, this capacity will be shut down for maintenance and when there are faults. It is also dependent on feedstock such as crude oil, which may be subject to supply disruptions or problems with transport infrastructure. Ensuring stocks of refined product to guard against unexpected disruptions would be equally necessary whether the country imports refined product or relies on imported crude for local refining. Here investment is necessary across the country in storage and transport infrastructure, from bulk storage tanks at the coast to pipelines and a network of storage facilities stretching inland. This needs to have the capacity to meet peak demand and for investments to be planned and implemented in advance of the demand growth in the country.

One approach is central coordination together with restricted licensing of access to ensure that those using it comply with the requirements of meeting demand. Another approach is to allow for rivalry between competing firms to anticipate demand, market products and craft service offerings for different customer requirements.

A distinction can be drawn between critical infrastructure, such as long-distance pipelines requiring substantial capital expenditure and advanced planning, and local depots, storage and retail facilities, which can easily be erected by different suppliers. For the first group of infrastructure there is stronger argument for coordination and regulation. For the second, access by a wider set of possible wholesale and retailers will likely increase the effectiveness of 
the network by bringing in traders and retailers who are closer to customers. This relies on ensuring access to the critical infrastructure on a relatively open basis and not restricting it to the select 'insiders' who have adopted the mantle of custodians of fuel supply.

The democratic state also faces the challenge of increasing economic participation, while not being subject to the same constraints regarding international supply as the apartheid state (of sanctions). In recent years there has been a growth of new suppliers and retailers. These include suppliers linked to agricultural co-operatives and farming requisites, such as 0 baro, as well as some engaged in wider wholesale and retail activities, led by Brent Oil, which has a national network of depots and fleet of tankers oriented to the commercial market. These smaller players have contributed to a substantially 'thicker' distribution infrastructure and different service offerings crafted to customer groupings. These developments were facilitated by the Petroleum Products Amendment Act no. 58 of 2003 promulgated in 2006, which provided for the licensing of persons involved in the manufacturing or sale of petroleum products to promote the transformation of the South African liquid fuels industry. This opened up space for independent wholesalers. The Liquid Fuels Wholesalers Association also claims that the oil companies wanted to move out of less attractive business, such as some segments of commercial sales and retail in rural areas, which then created a market for independent wholesalers.

Until the very recent changes, however, concerns around supply continued to be leveraged to protect the positions of the large oil company insiders. This has the further unintended consequence of maintaining very large interest groups with a stake in the status quo. Conversely, more diversified participation in supply implies less dependence on particular producers.

The evolving contestation and debates around new investment in refining have played out against the changing influence of different ideas. The belief in the importance of selfsufficiency in refined fuel has declined, and the debate is now more about the straightforward economic arguments. In these terms, the proposed new Sasol synfuels refinery (Mafutha) has apparently turned out to be much less attractive to Sasol given the capital cost and considerations such as the likely $\mathrm{CO}_{2}$ emissions and the cost thereof. The economic benefits to fuel consumers would depend on whether the investment meant more competitive pricing - at best a moot point, as it would simply add to the market share of Sasol, which is already dominant in the inland market (as determined by the Competition Tribunal in its ruling on the proposed Sasol-Engen (uHambo) merger). The consideration of the proposed Umthombo refinery needs to be done in similar terms.

With regard to Mafutha, the National Treasury noted in rejecting the proposal for tighter regulation of Sasol's inland market power as suggested by the Windfall Tax Task Team (WTTT) that it welcomed Sasol's commitment to the feasibility of investing in Project Mafutha and possible gas to liquids refining investments and that it would 'hold Sasol to its commitment to significantly expand its synthetic fuel production capacity in support of national interest in terms of fuel security and macroeconomic stability' (National Treasury, 2007). In the same response National Treasury also indicated that in 1998 cabinet had 'effectively' released Sasol from the obligation to repay the government subsidies it had received, provided Sasol continued to develop the petrochemicals sector. The fact that major investments in expanded refining capacity have not been made by Sasol raises the question about the appropriate response in terms of regulation of market power, to which we now turn. 


\section{PRICE REGULATION AND MARKET POWER}

We examine the evolving framework of price regulation in three main areas: first, how import parity benchmarks have been adopted to restrict pricing power overall in the country; second, the particular question of the inland market where Sasol is dominant and a low-cost producer; and, third, the influence that information exchange has had over competition.

The regulatory framework regulates prices at different levels from the refinery gate to wholesale and retail. This might suggest that there is a substantial concern about the potential exertion of market power which the DoE is seeking to remedy. However, the regulated prices are based on import parity benchmarks, including all transport and related costs, which effectively means that prices are set at the highest level that can be charged in the market. Ultimately, consumers are not much better off than they would be without regulation. Indeed, our review of the changes over time indicates that the prices set through regulation have been higher than those that could be charged at actual import prices. In addition, the prices posted under the regulatory framework also appear to have dampened competition, at least when combined with the information exchanged between firms on sales quantities (discussed later in the article).

\subsection{Calculating imputed import parity prices}

The aim of the initial import parity pricing system from the 1950s was to encourage import substitution. Given the small size of the economy, the oil companies wanted a guaranteed return. The mechanism of import parity implies using a price in a benchmark source country or countries, and adds to this all the costs associated with efficiently delivering that product to a particular location in South Africa to arrive at the regulated price. The economic rationale is that a seller may be expected to sell his/her product at or below the price at which the next nearest producer could deliver the product to that point of demand. If the country as a whole is short of refined product then imports would be the marginal source of supply. However, the import parity price set through regulation is an imputed price and does not necessarily reflect the price at which imports can actually be sourced.

This import parity price was calculated as an In-Bond Landed Cost (IBLC) until 2003, when there was a shift to the Basic Fuel Price calculation. The IBLC took an international product price calculated on as an average of a basket of $F O B$ (free on board) posted prices from four international refineries, and adding a hypothetical freight, insurance, leakage and landing charges for a South African port. IBLC was the refinery gate price for coastal refineries, and a premium was added in the form of hypothetical transport from the coast for inland refineries. The rationale for the IBLC was that the refineries should get the same prices for locally produced fuel as those they would have received had they imported fuel into the country (Lloyd, 2001).

It is now evident that there were various ways in which the IBLC calculation inflated prices above a true import price, directly inflating the margins of the oil refiners.

From 1973 the international price was based on the posted prices of three refineries in Singapore and one in Bahrain, which were owned and operated by the big four oil companies operating in South Africa (Marquard, 2006). This inflated prices in three ways.

First, Singapore was an inappropriate benchmark, as it was one of the most expensive refining areas from which to buy fuel. Since the Singapore markets consume mainly diesel rather than petrol, the petrol market was less developed and thus more expensive. In the South African market petrol is the most important petroleum product. Second, as Singapore is further from 
Durban than the Arab Gulf and Mediterranean Sea this increased the notional shipping cost. Third, the use of posted prices as opposed to spot prices meant higher prices. At least from 1970 on, spot prices were the standard basis for exports. This was a substantial mark-up, as posted prices were on average 10c/l higher than spot prices in 1997 (Marquard, 2006).

On the recommendation of the Liquid Fuels Industry Task Force (LFITF) in 1994, the reference refineries were changed and a Platts spot assessment was added as a fifth element (meaning one out of the five prices used was a spot price) (Marquard, 2006). The LFITF also recommended that the IBLC be calculated on a monthly basis, a practice that was adopted with the other changes in 1994.

In 2003 there was a move from the IBLC to the BFP (currently in use). A comparison between the IBLC and BFP over the period 1996 to September 2002 revealed that the BFP has on average been lower than the IBLC by four cents/litre for petrol, seven cents/litre for diesel, and 10 cents/litre for paraffin (SAPIA, 2003). The DME reported that every l c/litre saving in petrol and diesel was equivalent to about R150 million per year in South Africa at the time of change (Parliamentary Monitoring Group, 2003). The BFP is calculated as the average of daily spot prices from Singapore, Mediterranean (Italy) and the Arab Gulf to arrive at a monthly price for each product category. For petrol it is calculated on $50 \%$ Mediterranean (Italy) and $50 \%$ Singapore, while diesel is $50 \%$ Mediterranean and $50 \%$ Arab Gulf.

Freight, insurance and wharfage are added to arrive at the import parity price. These components are the same as those used in IBLC with the addition of the coastal storage cost and stock finance cost. The additions were at the request of the oil companies, and were an attempt to measure the true cost of importing petroleum products (Marquard, 2006).

The way in which the sea freight component has been calculated has also inflated prices over time. When the formula was devised tanker sizes were small; however, the tanker size used in the formula remained constant even though the average tanker size for transporting fuels had grown considerably larger and reduced the actual cost of transporting fuel considerably. The LFITF review led to freight charges being reduced from the levels that were in the IBLC.

The current formula for calculating BFP can be expressed as:

- Average CIF price $=$ FOB Spot prices \& Spot premiums, plus freight, including demurrage allowances and insurance)

- plus Ocean Loss Allowance

- plus Cargo Dues (Landed costs for imports at South African ports), plus Coastal Storage Cost, plus Stock Financing Cost.

The basic pricing formula in its current form has also been subject to various criticisms. The issues relate to whether BFP actually reflects the true Import Parity Price that it seeks to approximate (Rustomjee et al., 2007) and whether the BFP import parity pricing system is appropriate in the first place (Moerane et al., 2006). These issues are also recognised by the DoE, which has recently identified the need to review the BFP to determine its appropriateness (DoE, 2013). This arises mainly from concerns about the continuous increases in prices and the impact on economic growth, given that petroleum products are inputs to most business processes.

The debate about the appropriateness of the BFP must be understood in the context of the change in circumstances from the period that import parity pricing was adopted, when South 
Africa was importing most of its liquid fuel demand, to the current situation, where significant domestic liquid fuel consumption is met by domestic production. The price incentivised the oil companies to make investments in South Africa and compensated them for producing locally at the time of sanctions.

There are further questions about the quality of the fuel used in the BFP calculation, leading to the belief that the local industry has been benefiting through the difference in the fuel quality locally and the benchmark countries in the BFP calculation, especially prior to the implementation of the regulations on fuel quality specifications 'Clean Fuels l' in January 2006. The DoE has investigated this in relation to the difference between the current SA specifications versus current Euro specifications, and found that on balance the oil companies are not receiving undue benefits (DOE, 2013).

\subsection{Wholesale and retail margins}

To arrive at the final petrol pump price in the different fuel pricing zones (magisterial district zones), domestic costs, imposts, government taxes and margins are added to the BFP. In the current price structure this includes returns calculated for three main elements, namely, retail margin, wholesale margin and service differential. The retail margin is return on investment and cost recovery in the retail service station; wholesale margin is the return on investment and cost recovery in the wholesaling of petroleum products; and service differential is the return on investment and cost recovery in the secondary storage and secondary distribution of petroleum products to the final consumer.

These margins have been calculated on a rate of return basis. The wholesale margin is regulated and was initially in the form of the Petroleum Activities Return (PAR) mechanism, which was introduced in 1984. It applied the $15 \%$ overall return on assets managed benchmark, which had applied to the industry prior to 1984 and was intended to ensure that the industry achieved a return of around 15\%. In 1990 this was replaced by the Marketing of Petroleum Activities Return (MPAR), which applied to achieving benchmark returns for marketing assets only. The formula used to determine the wholesale margin was based on the results of a cost/financial investigation by a chartered accountant firm into the profitability of the wholesale marketers. The level of the margin was calculated on an industry basis and was aimed at granting marketers a return targeted at $15 \%$ (within a range of $10 \%$ to $20 \%$ ) on depreciated book values of assets, with allowance for additional depreciation, but before tax and payment of interest.

The methodology for the calculation of the margin required the consolidation and verification of results for the industry by an independent auditor, a process which historically took six to 12 months, with a significant part of the delays resulting from the industry itself being slow in delivering its results to the auditors. This would then delay adjustments to the margin; however, there was no mechanism to compensate for over/under-recovery.

Rate of return regulation has generally been criticised for inducing overspending on assets, known as 'gold-plating' (the Averch-Johnson effect). A guaranteed industry return of $10 \%$ to $20 \%$ (especially when lower inflation and interest rates meant that this was higher than risk-free returns) means that if the industry as a whole has more expensive assets than necessary then the higher return will simply be passed through to consumers.

The appropriateness of the MPAR has been questioned in the literature (see Lloyd, 2001; Moerane Investigation, 2005; Windfall Tax Task Team, 2007) and recommendations have been made for a re-evaluation of its usefulness as well as implementation. There is also an issue 
regarding the lack of transparency with regard to the calculation of the wholesale margin. Though the Dor refers to guidelines to calculate the MPAR wholesale margin, these are not available on the website. The MPAR was replaced by the Regulatory Accounting System (RAS) in 2010.

The main concern with the MPAR methodology is that though it determined the margins for wholesaling, retailing, storage and transport, it located the majority of the profits in wholesale.

The implementation of RAS separates these activities according to their location in the value chain, that is, all the retail activities are allocated under retail. However, the total margin will not be affected. RAS attempts to calculate a return for each part of the value chain where costs are incurred. The RAS return is made up of two main components: the investor margin (60.4 cents/litre in December 2013) and operating expenses cost recovery (78.7 cents per litre in December 2013). The return is calculated once a year using the capital asset pricing model (CAPM) based on a replacement value of the assets. The previous year's value is indexed until such a time that the where the exact replacement value can be sourced. When replacement values of assets are not available, the previous year's value in indexed. Depreciation is not taken into account. Secondary storage, secondary distribution, service differential and retail are separated as standalone activities.

The retail profit margin is also fixed by the DoE, and is determined on the basis of the actual costs incurred by the service station operator in selling petrol. In this cost structure, account is taken of all proportionate driveway-related costs such as rental, interest, labour, overheads and entrepreneurial compensation.

Government taxes include various indirect taxes and levies applicable to fuels sold locally, for example Customs and Excise Duties, Fuel Levy, Equalisation Fund Levy, Road Accident Fund Levy, IP Marker Levy, petroleum pipelines levy and the Demand Side Management Levy.

A sum of all these components results in the price that the consumer will pay for fuel. There are other aspects to fuels regulation that do not necessarily directly impact the calculation of the fuel price but impact on the state of competition in the market, for example import/export control.

It is important to note that additional rents that can be extracted from the retail level of the value chain through franchise fees, rentals etc. RAS was designed based on the retailer-owned, retailer-operated (RORO) service stations, which represent $40 \%$ of service stations in South Africa. The remaining $60 \%$ are company-owned retailer-operated (CORO).

The investment required to purchase a CORO service station is approximately R10 million, and the typical franchise agreements between the oil companies and the retailer last for three to five years. Prior to the RAS system the return for the retailer's investment was drawn from the 'entrepreneurial compensation', which in 2012 was approximately 20.3 cents per litre. Since the implementation of RAS, fuel retailers have complained that they are no longer receiving the 'entrepreneurial compensation'.

\subsection{Inland pricing}

Both the Competition Tribunal in its evaluation of the proposed Sasol-Engen (uHambo) merger and the WTTT identified Sasol as being dominant and having market power in the inland market due to the logistics constraints in bringing fuel inland. This implies that Sasol can charge prices 
up to inland import parity, by adding on the transport costs of bringing product from the coast. Indeed, this is part of the calculation of an inland BFP, which uses the pipeline cost.

If the inland region is short of fuel and is in effect a net importer, then product transported from the coast is meeting demand at the margin. However, Sasol's production costs are low, as reflected in the WTTT report, Sasol earns a fair return over costs when the oil price is at $\$ 28$ per barrel (WTTT citing an assessment by an independent study in 2000). The oil price has been around $\$ 100$ per barrel over recent years, meaning that Sasol has very high margins. In effect, Sasol has a location advantage from its inland position, on top of an advantage relative to crude oil refineries given the capital investments already made in synfuels and the low cost of the coal feedstock. However, it cannot necessarily command a full inland BFP, as it relies on customers with distribution infrastructure that are also the other major oil companies.

The Sasol-Engen merger hearing revealed the bargaining that occurred over the prices to be charged following the ending of the MSA, when the other oil companies were no longer required to buy Sasol's fuel (see Corbett et al., 2011). The effect was discounts off the inland BFP for a number of years, apparently until around 2007 (see non-confidential transcript of $\mathrm{Mr}$ MacDougall, Competition Tribunal Hearing, 2013:3585).

The WTTT identified the challenge of disciplining Sasol's ability to set prices up to the inland BFP in the absence of effective supply competition in the inland market as a target for regulation and/or appropriate fiscal measures. However, the WTTT also acknowledged the need to encourage increased investment in fuel production from local feedstock, which includes coal. It thus recommended a package of 'smart' regulation, which included regulation of inland prices inland at a level approximating competitive market prices (although this is open to much interpretation), a special levy on synfuels above a specified level and incentives for new investment in local fuels. As indicated above, no action was taken based on expectations about the investments Sasol was to make.

\subsection{Information exchange}

The price regulation allows for discounting off maximum prices in most cases, except for retail petrol. At the same time, the effective maximum price is posted by the DoE on a monthly basis at different levels of supply, such as through the posted Wholesale List Selling Price (WLSP) for most products. Competition between rivals will lead to discounts, while collusion has a readily available focal point.

The Competition Commission uncovered extensive sharing of information of sales volumes by the oil companies by magisterial district, customer category and fuel. What this means is that, until 2007, the oil companies could identify how much each of their supposed rivals was selling in each area. This undermines the incentives to compete through offering discounts, as the other companies will readily be able to identify this and respond (Das Nair \& Mncube, 2012). The Commission lodged a case of collusion against the oil companies on 24 October 2012 based largely on the companies exchanging information monthly on individual sales volumes to different customer categories by geographic area, in order to maintain profit levels above international norms. 


\section{GAS REGULATION}

We look at the case of natural gas in light of the review of fuel regulation. Sasol secured the rights to natural gas from the Mpande and Temane fields in Mozambique and, together with the governments of Mozambique and South Africa, has exploited this gas and constructed a pipeline of approximately $600 \mathrm{~km}$ to transport it to Secunda. There was no specific legislation for gas projects at the time (around 2000), and thus a regulatory regime had to be negotiated. The South African government and Sasol Gas concluded the RSA Regulatory Agreement, giving Sasol Gas a special regulatory dispensation regarding exclusive rights to ROMPCO's infrastructure (mainly the pipeline) for a period of 10 years from the first gas received by Sasol (from 2004 to 2014).

Shortly after the conclusion of this agreement the Gas Act of 2001 was enacted with the primary objective of promoting the efficient, effective, sustainable and orderly development and operation of gas transmission, storage, distribution, liquefaction and re-gasification facilities and the provision of efficient, effective and sustainable gas transmission, storage, distribution, liquefaction, re-gasification and trading services. Other objectives of the Act are to:

- facilitate investment in the gas industry;

- ensure that gas transmission, storage, distribution, trading, liquefaction and regasification services are provided on an equitable basis and that the interests and needs of all parties concerned are taken into consideration;

- promote the development of competitive markets for gas and gas services; and

- promote access to gas in an affordable and safe manner.

Sasol Gas's special regulatory dispensation came to an end on 25 March 2014. After this date, Nersa is mandated by the Gas Act, 2001, to approve maximum prices for all classes of customers of piped-gas and enforce non-discrimination. However, the requirement to approve maximum prices is contingent on Nersa determining that 'there is inadequate competition as contemplated in Chapters 2 and 3 of the Competition Act, 1998'.

During the special dispensation, in line with the provisions of the RSA Regulatory Agreement, Sasol priced using the 'market value pricing' (MVP) principle defined in the agreement as the determination of gas price in terms of:

- the cost of the alternative fuel delivered to the customer's premises; or anticipated place of use (in the case of Greenfields Customers); plus

- the difference between all the operating costs of the customer's use of the alternative fuel and all the operating costs of using natural gas; plus

- the difference between the Nett Present Value (NPV) of the capital costs of the customer's continued use of the alternative fuel and the NPV of the capital costs involved in switching to natural gas, as would be reflected in the customer's accounts.

Schedule one to the Agreement indicated that a price above the MVP would constitute noncompliance and a breach of Sasol Gas's licence conditions. This pricing methodology produced a price cap for Sasol Gas, and it could negotiate with individual customers. The discount is based on annual quantity purchased, and there were three categories of discounts (Nersa, 2006). 
Clause 8 of Schedule One of the Agreement also provides for a price cap on the average gas price that Sasol charges customers using up to ten (10) million gigajoules of gas per annum. The mechanism places a limit on Sasol's revenues from gas sales compared to a benchmark established using prices of several European countries, known as the European Benchmark Price $(\varepsilon B P)$ comprising the Netherlands, Spain, Belgium, Italy, France and Germany. The Sasol Volume Weighted Average Gas Price for customers may not exceed the EBP (Nersa, 2006). In the event that it does customers may claim refunds from Sasol Gas.

In effect, the MVP is simply the maximum price that Sasol Gas can charge while still attracting customers to switch from other energy sources to natural gas. Note, however, that attracting customers to switch means Sasol Gas bearing the costs in terms of a lower price to the customer. At no point was the weighted average price above the $\varepsilon B P$, although the weighting means that the computed average price is almost entirely due to large customers, which includes the prices charged to customers which are associated with Sasol itself (such as Springlights Gas in which Sasol has a substantial shareholding).

Nersa did receive a number of complaints from customers about the implementation of the regulated price, and Nersa's investigations suggested that there were discrepancies in Sasol Gas's implementation (Nersa, 2007). However, it is not clear what (if any) steps were taken.

\subsection{Proposed pricing from March 2014}

In 2011 Nersa published its proposed methodology for the calculation of maximum gas prices from March 2014 onwards. This sets the maximum gas price against a basket of alternative fuels in South Africa. There are also tariff guidelines applicable to the transmission, storage and reticulation of gas. We focus here on the maximum gas price regulation.

Using a yardstick approach to determine maximum prices is a recognised method of price regulation and avoids the pitfalls of rate of return, such as the 'gold-plating' referred to above. Its outcome depends on the suitability of the yardstick chosen. The maximum gas price weights the prices of alternative fuels based on the total energy consumption of coal, diesel, electricity, heavy fuel oil (HFO) and LPG. This means that coal has a weight of $36.2 \%$, diesel $24.8 \%$ and electricity $37.1 \%$, with HFO and LPG collectively accounting for just $3 \%$. The prices used for coal, diesel and electricity are thus critical to the outcome.

The coal price that is used in the determination is the FOB thermal coal price at Richards Bay Coal Terminal (converted into Rands per gigajoule). This is thus not the coal price that users of gas are likely to have been using as an alternative for two reasons. First, South Africa exports high-quality coal while it consumes low-quality coal, and this translates into much higher export prices than domestic prices. Second, most industry gas users are inland, and the inland coal price (for export grade coal) is lower than at Richards Bay by the transport cost to transport coal to the coast. Second, most industry gas users are in the inland region, where most coal mines are also located, and the Richards Bay price is inclusive of transport to the coast and loading cost (onto a ship), which are not incurred in delivery inland customers. There are therefore significant price differences for coal consumed locally and export coal.

The diesel price used is the basic fuel price for diesel, per litre, converted to Rands per gigajoule. The data is sourced from the Department of Energy. As the inland diesel price is higher than the (coastal) BFP this is lower than it would be for inland consumers. However, the weight of diesel reflects national energy use (mainly for road vehicles) rather than the proportion of industry users that use diesel. 
The electricity price is the Eskom average tariff approved by the Energy Regulator, per kWh converted into Rands per gigajoule. The average tariff approved by the Energy Regulator is an average of all Eskom's customer groupings. Large industrial customers (a substantial proportion of consumers of piped gas) pay less than the average Eskom Tariff. This means that the electricity indicator used in the calculation of maximum gas prices is higher than it would be had an average price for industry users been adopted.

Sasol Gas Ltd has applied for, and Nersa has approved, maximum gas prices for the prescribed customer categories for a multi-year period from 26 March 2014 to 30 June 2017 (TABLE 2).

TABLE 2: Approved Maximum Piped Gas Price

\begin{tabular}{|c|c|c|c|c|c|c|}
\hline & GJ p.a. & $\begin{array}{c}\text { Gas Energy } \\
\text { Price (GE) } \\
-R / G J \\
\text { forecast } \\
2014\end{array}$ & $\begin{array}{c}\text { Reductions } \\
\%\end{array}$ & $\begin{array}{c}\text { Reduction } \\
\quad(R / G))\end{array}$ & $\begin{array}{c}\text { SasolGE } \\
(R / G J) \\
(26 / 3 / 2014)\end{array}$ & $\begin{array}{c}\text { Nersa } \\
\text { approved } \\
(26 / 3 / 2013)\end{array}$ \\
\hline Class 1 & $<400$ & 128 & $7.50 \%$ & 9.6 & Rl18 & R108.86 \\
\hline Class 2 & $401-4000$ & 128 & $7.50 \%$ & 9.6 & R118 & R108.86 \\
\hline Class 3 & $4001-40000$ & 128 & $15.00 \%$ & 19.2 & R109 & $\mathrm{R} 100.04$ \\
\hline Class 4 & $40001-400000$ & 128 & $22.50 \%$ & 28.8 & R99 & R91.21 \\
\hline Class 5 & $400001-4000000$ & 128 & $30.00 \%$ & 38.4 & R90 & R82.38 \\
\hline Class 6 & $>4000000$ & 128 & $37.50 \%$ & 48 & R80 & R73.56 \\
\hline
\end{tabular}

Source: Nersa consultation document

$80 \%$ of Sasol Gas customers (by number, not volume) were expected to receive price reductions after the implementation of the approved maximum prices (Creamer, 2013). This is corroborated by the Nersa consultation document, which states that most of the small customers may receive price decreases (Nersa, 2007).

TABLE 3: Breakdown of price increases by customer size

\begin{tabular}{lcccc}
\hline & Total & Total (\%) & volume & Volume (\%) \\
\hline "Small customers that may face decreases & 268 & $58 \%$ & 1872400 & $3 \%$ \\
Small customers that may face increases & 74 & $16 \%$ & 1227600 & $2 \%$ \\
"Large customers that may face decreases & 66 & $14 \%$ & 22323100 & $36 \%$ \\
Large customers that may face increases & 57 & $12 \%$ & 36576900 & $59 \%$ \\
Total customers & 465 & $100 \%$ & 62000000 & $100 \%$ \\
All customers facing price decreases & & $72 \%$ & & $39 \%$ \\
All customers facing price increase & & $28 \%$ & & $61 \%$ \\
\hline
\end{tabular}

Source: derived from data in the Piped Gas consultation document of 26 March 2013

Notes: *Small customers are Class 1-3; \#large customers are Class 4-6 
However, it is important to break down the customers that are expected to receive price decreases relative to the total volumes sold to external customers (TABLE 3 ).

Although the approved maximum gas price may result in a decrease in prices for customers, it is more appropriate to look at this in terms of the volumes purchased by the customers and not simply the number of customers. This gives an indication of the impact of the balance of price increases and decreases on the economy. Sasol's application simply applies the methodology published by Nersa in 2011 and does not give any further details. We assess the outcomes by first comparing South African natural gas prices to other countries, undertake an illustrative exercise to examine what the different prices and weights would have realised had they been implemented in 2011, and then check if Sasol Gas has been profitable in the years leading to the change in methodology.

A comparison of South African natural gas prices to 15 countries, including the 6 "European Benchmark Price" countries, shows that South Africa has the second-highest gas prices out of the surveyed countries and was higher than all 6 "European Benchmark Price" Countries (FIGURE 1).

A comparison using a different data set shows the South African natural gas prices falling within the lowest third in a ranking from highest-priced to lowest-priced European Union economies (FIGURE 2). This picture is different partly because of the inclusion of a large number of higherpriced, gas-importing European countries. The gas price arrived at for Class 3 customers (industrial customers using between 4,001GJ and 40,000GJ) in South Africa compares relatively favourably with prices for larger customers in the European Union.

We consider the impact of the choice of weights and prices for alternative energy sources by considering what prices would have been realised under different scenarios for 2011. Using weights for energy sources based on industry usage has the effect of increasing the coal and electricity weights substantially to $49.55 \%$ and $44.96 \%$ respectively, while the diesel weight falls to just $5.45 \%$ (DoE, 2012). As diesel is the most expensive fuel this reduces the maximum price substantially, by $17 \%$ (TABLE 4).

Second, we consider the effect of using an inland coal price rather than the export FOB Richards Bay price, which reduces the gas price by $7 \%$ (DOE, 2012). Third, we consider the impact of using an industrial electricity tariff rather than the average Eskom tariff, and the gas price is reduced by $8 \%$ (DOE, 2011). Taken together, these changes would reduce the maximum gas price calculated following the Nersa methodology for 2014 (applied to 2011 data) from R103.40 to R87.16 (TABLE 4). 
Mondliwa \& Roberts

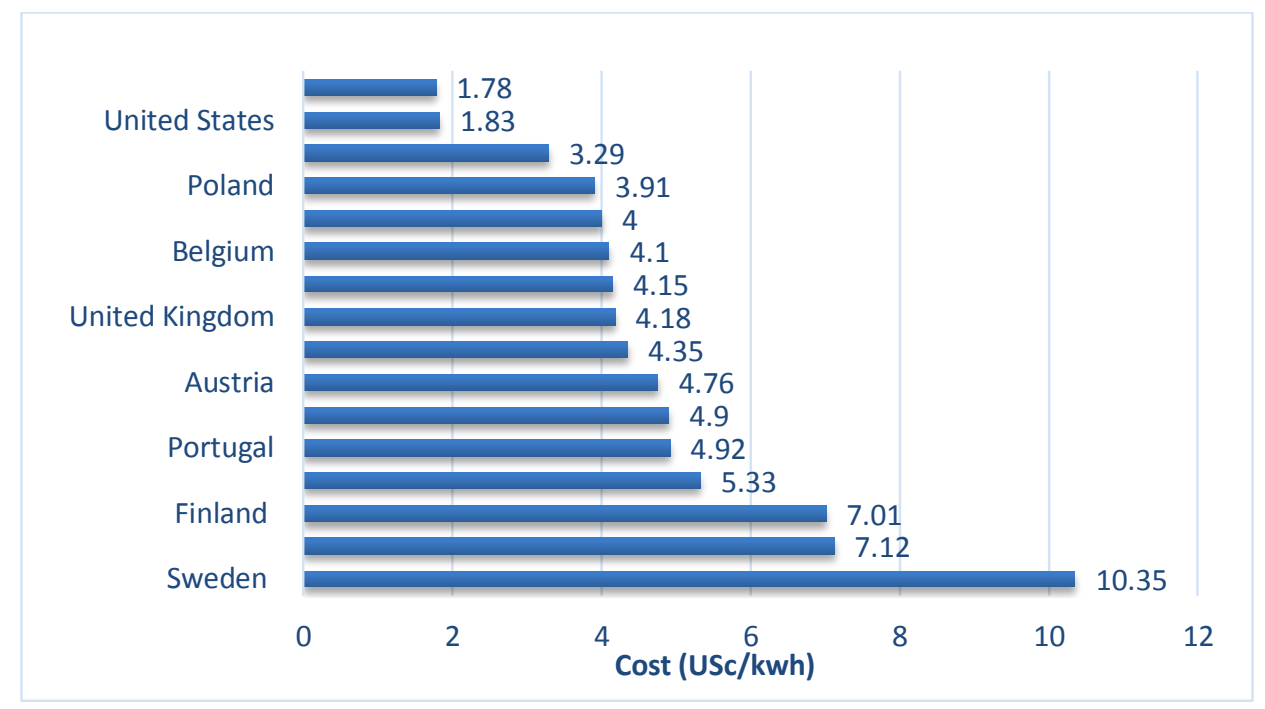

FIGURE 3: 2012 International Natural Gas Cost Comparison

Source: NUS Consulting Group's 2011-2012 International Electricity \& Natural Gas Report and Price Survey

Note: The survey is based on prices as of 1 June 2012 for a natural gas supply of 1,250,000 kWh per month, in US cents excluding VAT.

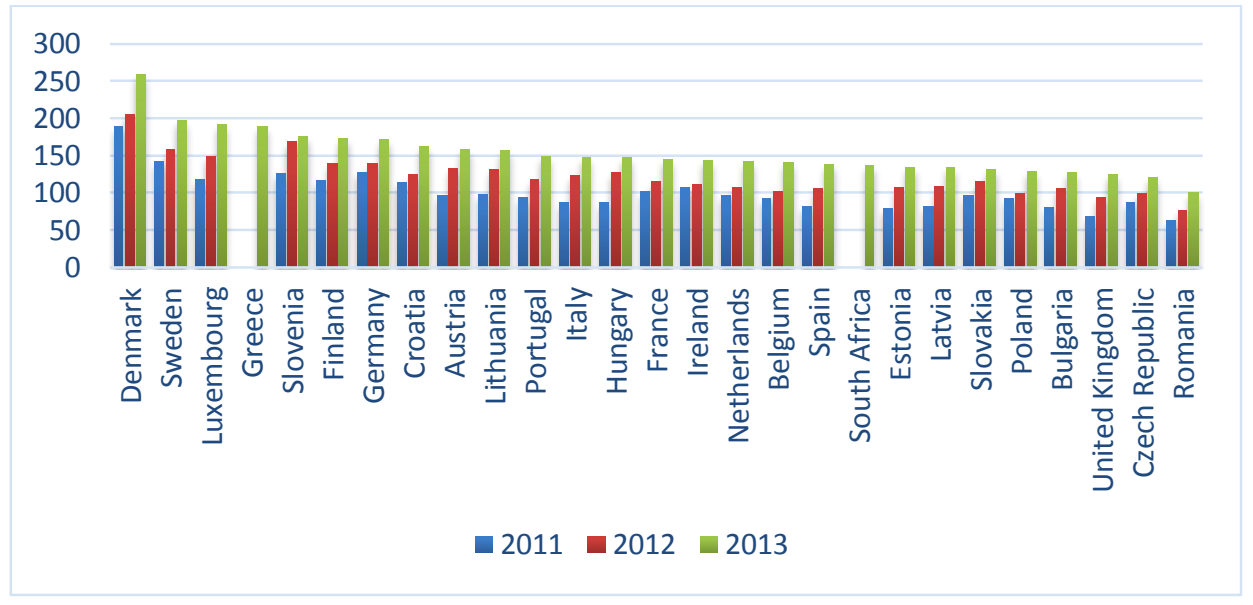

FIGURE 2: South Africa Class 3 price in Gauteng as at March 2013 (4,001G - 40,000G) per annum, including Sasol tariffs) compared to $\varepsilon U$ industrial tariffs $(10,000 \mathrm{GJ}$ 100,000GJ per annum) (ZAR / GJ)*

Source: Eurostat

* Exchange rates: 2011: R10.06/عUR; 2012: R10.50/عUR; 2013: R12.79/عUR 
TABLE 4: Illustrative calculation of maximum gas prices under different weights and prices for alternative fuels

\begin{tabular}{lccccc}
\hline & Weights $A$ & $\begin{array}{c}\text { Nersa Price } \\
(R / G)\end{array}$ & $\begin{array}{c}\text { Price-A } \\
(R / G)\end{array}$ & Weights-B & $\begin{array}{c}\text { Price- } B \\
(R / G J)\end{array}$ \\
\hline Coal & $36.2 \%$ & 11.29 & 2.63 & $49.55 \%$ & 3.60 \\
Diesel & $24.8 \%$ & 38.62 & 38.62 & $5.45 \%$ & 8.49 \\
Electricity & $37.1 \%$ & 50.97 & 43.40 & $44.96 \%$ & 52.61 \\
HFO & $1.1 \%$ & 1.40 & 1.40 & $0.04 \%$ & 0.05 \\
LPG & $0.8 \%$ & 1.11 & 1.11 & $0 \%$ & 0.00 \\
Weighted Maximum & $100 \%$ & 103.40 & 87.16 & $100 \%$ & 64.75 \\
\hline
\end{tabular}

Notes and sources: Weights-A are the weights prescribed by Nersa calculated on the overall consumption of the selected energy indicators for 2008. Weights-B are calculated based on the DoE's industry consumption of the selected energy indicators, for 2008. Nersa price is the maximum gas price for 2011 as per the Nersa methodology and benchmarks. Price-A is calculated using the formula stipulated in the Nersa maximum price methodology but substituting the export FOB coal price with the local FOR price and the average Eskom tariff with the Eskom industrial tariff. Both the FOR coal price and the Industrial electricity tariff are sourced from the DoE South African Energy Price Report, 2012. Price-B changes the coal and electricity prices, and the gas price is calculated using Weights- $B$.

If we assess Sasol Gas's profit margins over the last few years we observe that Sasol Gas has been making an operating profit margin in the range between $38 \%$ and $47 \%$ (TABLE 5).

TABLE 5: Sasol Gas Turnover and Operating Profit

\begin{tabular}{lccccccccc}
\hline $\begin{array}{l}\text { SA Energy: Sasol Gas } \\
\text { Financial Year }\end{array}$ & & 2012 & 2011 & 2010 & 2009 & 2008 & 2007 & 2006 & 2005 \\
\hline Turnover & $\mathrm{R} \mathrm{m}$ & 6931 & 5445 & 5371 & 5666 & 4697 & 3702 & 3209 & 2404 \\
Operating profit & $\mathrm{R} \mathrm{m}$ & 2985 & 2578 & 2479 & 2424 & 1785 & 1936 & 1526 & 931 \\
Operating profit margin & $\%$ & 43 & 47 & 46 & 43 & 38 & 52 & 48 & 39 \\
\hline
\end{tabular}

Source: Sasol Group Limited Financial Statements

One expects that these overall price increases will result in higher profit margins for the monopoly supplier.

To soften the blow, Sasol has committed to a transitional price mechanism whereby prices will be increased in tranches. For those with price increases between $15 \%$ and $30 \%, 15 \%$ will apply on 26 March 2014 and the remainder will be applied on a quarterly basis between March 2014 and March 2015. For those customers that that are faced with price increases between $30 \%$ and $45 \%$, $15 \%$ will be applied on March 2014, and the difference will be spread over the period between March 2014 and March 2016. 
Large industrial users of gas have objected to the methodology and resulting prices, indicating that gas represents approximately $20 \%$ of large manufacturers' input costs, and the proposed increases will put pressure on the margins of these firms (Creamer, 2013). These customers have complained that the new pricing methodology is disadvantaging those who have invested in switching to gas, which is perceived to be more efficient and affordable (Radebe, 2013).

Nersa was reported as stating that the methodology was designed to attract investors in the gas market by offering high returns (Mail and Guardian, 2013). Nersa has to balance the desire for fair and competitive pricing with the need to ensure that the gas sector becomes more attractive for investors as per the Gas Act of 2001. In such an assessment, Nersa would have to consider whether there are likely entrants into the market for inland gas supply and in what time period, given that this new dispensation is in place for three years. If entry is indeed unlikely then regulation may be ensuring that Sasol Gas enjoys monopoly profits at the expense of the customers.

It can also be argued that the discounted gas price and not only the methodology for maximum gas prices needs to be taken into account. This is correct, although it also implies that an entrant would need to consider the discounted prices that Sasol would offer on entry, and not the prevailing price. The experience of liquid fuels regulation highlighted the importance of the choice of benchmarks to use; however, it appears as though these lessons were not taken on board when the maximum piped gas regime was established. We have shown that the outcome of the maximum gas price calculation can differ significantly as a function of choice of benchmarks to be used in calculations.

\section{CONCLUSIONS}

We sum up by considering the regulatory record against the objectives of ensuring security of supply, restricting the exertion of market power, incentivising investment and opening up participation in the sector. At a high level, there are strong threads of continuity.

The South African fuel pricing system based on IPP was generous during the apartheid years, ensured the profitability of the oil companies and provided an incentive to the multinationals initially to invest in refining assets, and subsequently to remain in South Africa despite pressures to disinvest due to sanctions. Although there are no longer sanctions against South Africa, local refining on the grounds of security of supply has continued to have the greatest weight, rather than a reorientation to trading and distribution to ensure customer-responsive supply.

There have been changes in terms of amendments to the import-parity-based system for liquid fuels to obtain measures closer to the actual cost of importing fuel. In addition, there has been entry into distribution and retail. However, the core challenges identified by the WTTT remain, and the apparent conditions for their recommendations to be set aside have not been met in the form of substantial investments upstream in new refining capacity. The amendments to the import parity measure reveal just how much additional margin was being made by upstream refiners. The significance of different benchmarks and sources of information also highlights how information asymmetry in favour of the industry players can advantage these interests over those of consumers. Moreover, the basis for determining the price of liquid fuels has not changed, in particular, with regard to taking into account Sasol's privileged position in the inland region and very low costs. While the gas price has moved to using a yardstick, or 
benchmark approach, the choice of components in the benchmark has favoured the supplier, again apparently on the grounds of incentives for investment.

The WTTT recommended that fuel-price regulation could be reduced to price-cap regulation for a period of time to determine what aspects of regulation will be required going forward, and the prohibition of discounting and purchasing incentives should be discontinued. It also recommended that the quantitative import controls should be removed, allowing increased participation in the importation and trading of liquid fuels. Furthermore, there should be a combination of tighter price regulation in the inland market and taxation of the windfall profits of synfuels (being a windfall from the low-cost coal feedstock), coupled with investment incentives to stimulate new capacity.

Rather than relaxing regulation downstream, greater attention has been paid to trying to estimate costs and rates of return in wholesaling, storage and retail, which is very demanding in terms of information and analysis. With tighter upstream regulation and increased participation in wholesale and retail (as we have started to see), increased competition would mean less need to micro-regulate downstream activities.

\section{Acknowledgement}

This article draws on research undertaken as part of the Regulatory Entities Capacity Building Project, with funding from the South African government's Economic Development Department.

\section{LIST OF REFERENCES}

Amsden, A. (2003). The Rise of 'The Rest': Challenges to the West from Late-Industrializing Economies. New York: Oxford University Press.

Competition Tribunal (2006). Decision in Sasol - Engen Merger, case 101/LM/Dec04

Competition Commission (2012, 0ctober 14) 'Competition Commission refers a case of collusion against oil companies' [Press release]. [Online] Available:

http://www.compcom.co.za/assets/Uploads/AttachedFiles/MyDocuments/CompetitionCommission-refers-a-case-of-collusion-against-oil-companies.pdf. (Accessed 24 January 2014).

Competition Tribunal Hearing (2013). Competition Commission v Sasol Chemical Industries. Case number 48/CR/Auglo (non-confidential)

Corbett, C., Das Nair, R. \& Roberts, S. (2011). Bargaining power and market definition: a reflection on two mergers. Journal of Economic and Financial Sciences, 4(2), pp. 147-166.

Creamer, T. (2013). Big Manufacturers Turn to Courts amid Unhappiness with-Gas Pricing Sasol Contract Talks. [Online] Available: www.engineeringnews.co.za. (Accessed 10 November 2013).

Das Nair, R. \& Mncube, L. (2012). The role of information exchange in facilitating collusion-insights from selected cases. In Moodaliyar, K. \& Roberts, S. (eds.) The development of competition law and economics in South Africa, HSRC Press. 
Das Nair, R., Mondliwa, P. \& Roberts, S. (2012). The inter-relationships between regulation and competition enforcement: Regulating for competition? Remedying anti-competitive behaviour through regulation? Paper presented at the South African Economic Regulators Conference, Johannesburg, August 2012.

Department of Energy (DOE) (2013). South African Energy Price Report 2012. [Online] Available: http://www.energy.gov.za.

Farmers Weekly (2013). Manufacturers Steamed up over New Gas tariffs. [Online] Available: www.farmersweekly.co.za. (Accessed 10 November 2013).

Jalilian, H., Kirkpatrick, C. \& Parker, D. (2006). Creating conditions for international business expansion: the impact of regulation on economic growth in developing countries - a cross country analysis. In Amann, દ. (ed) Regulating Development: Evidence from Africa and Latin America. Cheltenham: Edward Elgar Publishing Limited.

Lloyd. P. (2001). The South African Petroleum Industry: A Review. Automobile Association.

Mail and Guardian (2013). Nersa Says Gas Market is Good for Investment. [Online] Available: www.mg.co.za. (Accessed January 2014)

Marquard, A. (2006). The origins and development of South Africa's energy policy. Unpublished DPhil thesis, Department of Engineering and Built Environment, University of Cape Town.

Moerane (2006). Report of the Moerane Investigating Team to the Minister of Minerals and Energy on the December 2005 Fuel Shortages. [Online] Available:

http://www.energy.gov.za/files/esources/pdfs/moerane_fuel_investigation.pdf. (Accessed 20 November 2013)

National Treasury (2007). 'Windfall Taxes in the Liquid Fuels Industry. Response to the task team report on windfall products in the liquid fuels industry.'

National Energy Regulator of South Africa (Nersa) (2011). 'Methodology to approve Maximum Prices of Piped-Gas in South Africa'.

National Energy Regulator of South Africa (Nersa) (2006). 'Price Regulation of Piped-Gas 2005/6' [Online] Available:

http://www.nersa.org.za/Admin/Document/Editor/file/Piped\%20Gas/Consultations/Presentations/ Gas\%20brochure\%20prices.pdf (Accessed 13 November 2013).

National Energy Regulator of South Africa (Nersa) (2007). 'Market Value Pricing Explanatory Notes' [Online] Available:

http://www.nersa.org.za/Admin/Document/Editor/file/Piped\%20Gas/Pricing\%20and\%20Tariffs/Pric ing\%20Decisions/Current/Market\%20Value\%20Pricing\%20Explanatory.pdf (Accessed 13 November 2013).

National Energy Regulator of South Africa (Nersa) (2011). 'Data Sources for the Implementation of the Methodology to Approve Maximum Prices of Piped-Gas in South Africa' [Online] Available:

http://new.nersa.org.za/SiteResources/documents/Data\%20Sources\%20-\%20PipedGas\%20Maximum\%20Prices\%20Methodology.pdf (Accessed 13 November 2013).

Sibiya. R. (2013). The Journey: South African Liquid Fuels Retailing Sector. Forecourt Times, 2013 Edition, pp. 8-9.

Radebe, K. (2013). SA Gas the Most Uncompetitive Prices Globally. [Online] Available: www.moneyweb.co.za. (Accessed January 2014). 
Rustomjee, Z., Crompton, R., Mehlomakulu, B. \& Steyn, G. (Windfall Tax Task Team) (2007). Possible reforms to the fiscal regime applicable to windfall profits in South Africa's liquid fuel energy sector, with particular reference to the synthetic fuel industry. Report for National Treasury, 9 February 2007 Rustomjee, Z. (2012). Witness Statement in Competition Commission v Sasol Chemical Industries. Case number 48/CR/Aug10 (non-confidential)

SAPIA (2012). Annual Reports

SAPIA (2013). Annual reports

Sasol (2012). Annual Reports

Viscusi, W.K., Vernon, J. \& Harrington, J. (2000). Economics of Regulation and Antitrust. Cambridge Mass: The MIT Press. 
Mondliwa \& Roberts 